\title{
The Effectiveness of Psychoeducational Group with Group Exercises Technique to Improve Student's Self-Efficacy
}

\author{
Riana Wibi Pangestuti ${ }^{1 *}$, Mungin Eddy Wibowo ${ }^{2}$, Muhammad Japar ${ }^{3}$ \\ Universitas Ahmad Dahlan Yogyakarta, Indonesia ${ }^{1}$ \\ Universitas Negeri Semarang, Indonesia ${ }^{2}$ \\ Universitas Muhammadiyah Magelang, Indonesia ${ }^{3}$ \\ Qriana@kesatuanbangsa.sch.id ${ }^{1 *}$
}

Article Information:

Received December 23, 2019

Revised December 26, 2019

Accepted December 29, 2019

Keywords: group exercises training, psychoeducational group, self-efficacy

\begin{abstract}
Self-efficacy is a determining factor to achieve the learning objectives. Therefore, self-efficacy is important to be measured and improved. This study aimed to examine the effectiveness of a psychoeducational group with exercises techniques to improve students' self-efficacy. This study was carried out by using a pretest-posttest control group design by involving 2 groups, the experimental and control group. The data from these groups were analyzed using repeated-measure MIX MANOVA. Meanwhile, the authors used self-efficacy scale $(\alpha=0.911)$ to collect the data of 14 students. The results showed that there were effects of time in the improvement of students' self-efficacy $(F(2)=1,746 ; p<0.05)$, group members effect $(F(3,984)=8,442 ; p<0.05)$, and the effect of time interacting with group members $(F(1,293)=0.045 ; p<0.05)$. It can be concluded that the psychoeducational group with exercises techniques is effective to improve students' self-efficacy by regarding the duration of intervention, group member, and time interaction with group members. This study implication to the guidance and counseling services will be discussed.
\end{abstract}

\section{INTRODUCTION}

High school students are in the transition phase to adolescence (Schaffhuser et al., 2017). In this phase, they experience some changes which may affect their behaviors (Harter, 2015). Therefore, the students need to have high self-efficacy to move forward. It is because self-efficacy is a very influential aspect for the development of students' personality and learning achievement (Chiaburu \& Lindsay, 2008; Costa et al., 2016).

Schunk \& DiBenedetto (2020) states that Self-efficacy is both evaluative and goal oriented, is a key internal motivational proces. Thus, self-efficacy is a determining factor for the achievement of the desired learning objectives. Self-efficacy is basically a cognitive process which covers decision, belief, or expectation about how far individuals estimate their own abilities to perform tasks or particular actions required to achieve the desired results (Bandura, 1977).

Bandura (1977) explains that the existence of self-efficacy would determine actions someone will perform, the number of efforts to do in an activity, how strong and sustainable individuals can survive within obstacles and failure, and how success or failures in a task influence the behaviors of the individuals in the future. The high self-efficacy would result in better efforts and perseverance in dealing with problems and achieving goals. Oppositely, low

How to cite:

E-ISSN:

Published by:
Pangestuti, R., Wibowo, M., \& Japar, M. (2020). The Effectiveness of Psychoeducational Group with Exercises Techniques to Improve Student's Self-Efficacy. Islamic Guidance and Counseling Journal, 3(1). https://doi.org/10.25217/igcj.v3i1.673 2614-1566

Institut Agama Islam Ma'arif NU (IAIMNU) Metro Lampung 
self-efficacy would result in disappointment which further causes high stressors (Schunk \& DiBenedetto, 2020).

The role of self-efficacy in daily life would direct individuals to achieve challenging goals, and survive in facing difficulties (Schunk \& DiBenedetto, 2020; Schunk et al., 2012). It shows that self-efficacy provides a pretty strong contribution to one's resilience (Cassidy, 2015; Wang et al., 2018). Therefore, it is needed in facing all difficulties in life.

When self-efficacy is high, they believe that they can perform certain responses to gain reinforcement (Rotter, 1954). In relation to this, students who have high self-efficacy would have beliefs and abilities to perform tasks (Stajkovic et al., 2018). Moreover, they also have stability and commitment in achieving the desired goals. Conversely, they will be anxious that they cannot respond to all those demands.

Low self-efficacy can be seen from their daily attitudes and behaviors at school. It is in line with what is stated by Septiningtyas et al., (2020) that students who have low selfefficacy are realized by having the following atittudes a) being passive, b) avoiding difficult tasks, c) developing difficult aspirations, d) developing low aspirations, e) never trying to do something, f) always giving up and having no passion, g) blaming the past for the lack of ability, h) being worried, stressful, and helpless, and i) looking for justification for failures.

Students' condition in the field showed that many challenging academic assignment often made students lead to uncertainty rised from new experiences (Brady et al., 2018). This uncertainty would cause anxious thoughts and feelings. When these continously happen, students will be vulnerable to stress (Frazier et al., 2019). This condition arises because of the low self-efficacy of students, so they could not develop due to the negative stress.

Regarding the importance of providing assistance to students, guidance and counseling teachers should prepare the right services. In this study, the service aimed to the low selfefficacy experienced by students. One technique that is applicable for this problem is the provision of psychoeducational group with group exercises techniques.

Group exercises technique is a technique implemented in a psychoeducational group with the orientation of making the group members active, mobile, and dynamic. Jacobs et al. (2011) says that exercises give someone chances to learn through experiences. These can also be used as an alternative approach to discover any issues within activities.

High level of self-efficacy shows students' confidence in being able to overcome various difficult situations related to the academic process so that they can overcome the demands and high academic burdens (Cassidy, 2015; Schunk et al., 2012). Self-efficacy will encourage students to enjoy learning activities and maintain attention to various academic tasks (Sunawan et al., 2017). People who have a high level of selfefficacy will easily overcome changes in the environment and will take advantage of available opportunities with their ability to develop their potential (Gündüz, 2012). Therefore, it is essential to use a psychoeducational group which can improve self-efficacy (Shimazu et al., 2005). One technique that can be used is experiential learning (Tompson \& Dass, 2000). Pintrich, Meece, and Schunk (1996) believe that students who have a high level of self-efficacy will correlate with optimal self-development.

Several studies prove that group counseling model with problem solving techniques to improve students' academic self-efficacy (Setiawan, 2015; Sohrabi et al., 2013), group with cognitive behavior therapy approach (Hyun et al., 2005), life skills training (Shechtman et al., 2005), motivational interviewing (Walpole et al., 2013), psychoeducational group with role playing technique (Ana et al., 2017), and experimental learning (Novita \& Hidayah, 2016; Zaroh, 2018). All of those interventions are effective to improve self-efficacy.

Self-efficacy needs to be developed continuously so that every individual can survive and face pressure, demands, and challenges in the stages of development. In addition, training is one effort to develop human resources to make individuals be more effective. The training 
is preventive and developmental. It is similar to the function of basic service that is to help all students in developing effective behaviors, and life skills which refer to the developmental tasks (Nurihsan, 2007).

What differs this study from other studies is that the current study used some group exercises to improve self-efficacy, such as experimental, group-decision, and dyads and triads exercises (Jacobs et al., 2011). While other studies only used one technique in group exercises, such as problem solving, role playing, or experimental learning. This study not only focused on one group exercise, but also other effective techniques to improve self-efficacy. There are several exercises which are able to be used in group exercises. The selection of this exercises have been done based on the needs covering problems, age, cultural background, and group member's needs. This study has different characteristics compared to the others study. It was clarified in the objectives, namely to determine and analyze the effectiveness of psychoeducational group with group exercises techniques to improve students' self-efficacy.

\section{METHODS}

The subjects of this study were the tenth grade students of Public Vocational high school 7 Bandung amounted to 132 students. They were invited based on purposive sampling, the low level of self-efficacy. The participants 14 students were divided into two groups, namely experimental group and control group.

The instrument used in this study was self-efficacy scale instrument. Development of a self efficacy instrument lattice based on conceptual and operational definitions used in research. The level of self-efficacy (self efficacy) is measured using a scale compiled by researchers based on self-efficacy indicators (self efficacy) which are formulated into five indicators, namely: 1) sure can complete certain tasks, 2) sure can motivate themselves to take necessary actions in completing a task, 3) sure that you are able to try hard, persistent, and persevering, 4) sure that you are able to survive facing obstacles and difficulties, and 5) sure you can complete tasks that have a wide or narrow range (specific).

Psychological scale research instruments compiled by researchers to measure the selfefficacy of students who use the Likert scale is a scale used to measure attitudes, opinions, perceptions of a person or group about social events or symptoms (Riduwan, 2011). There are five alternative answers, namely Very Appropriate, Appropriate, Less Conforming, NonConforming, and Very Unsuitable, with a score distribution of 1, 2, 3, 4, 5. Respondents will be asked to answer the statements contained in the questionnaire by selecting an alternative answer by giving a check mark $(\sqrt{ })$ on the answer sheet. It consisted of 32 items. This instrument has passed the validity test and gained ( $\mathrm{rxy}=0.001-0.05, \alpha=0.911$ ).

The researchers employed quantitative approach in this study. For more, the experimental design applied was pretest-posttest control group design involving two groups, namely experimental and control groups (Purwanto, 2013). The intervention provided to the experimental group was in form of psychoeducational group with group exercises technique, while the control group received the intervention with no group exercises technique or placebo group.

There were several procedures performed by the researchers. First, determining the pretest standards to measure the students' self-efficacy level prior to the intervention. Second, the provision of intervention to the experimental group in form of the psychoeducational group with group exercises technique. Each group conducted five times meeting with the time allotment of $2 \times 45$ minutes for each. Third, the researchers provided posttest to the subjects to observe the improvement of self-efficacy. Fourth, the researchers performed follow-up activities in each group within two weeks after the posttest. The data collected from pretest, posttest, and follow-up were analyzed using repeated measure MIX MANOVA to see the improvement. 


\section{RESULTS AND DISCUSSION}

Based on the data description on Table 1, it was known that the mean and standard deviation of pretest, posttest and follow-up of the experimental group gained improvement $(\mathrm{M}=103 ; \mathrm{SD}=7.746)$, posttest $(\mathrm{M}=105.3 ; \mathrm{SD}=6.157)$ and follow-up $(\mathrm{M}=105 ; \mathrm{SD}=7.703)$ respectively. Additionally, control group obtained the pretest score of $(\mathrm{M}=112.9 ; \mathrm{SD}=9.599)$, posttest score of $(M=119.1 ; S D=8.877)$ and follow-up score of $(M=115 ; S D=9.238)$.

\begin{tabular}{lccc}
\hline & & Experimental & Control \\
\hline Pre-test & M & 103 & 112.9 \\
& SD & 7.746 & 9.599 \\
Post-test & M & 105.3 & 119.1 \\
& SD & 6.157 & 8.877 \\
Follow-up & M & 105 & 115 \\
& SD & 7.703 & 9.238 \\
\hline
\end{tabular}

Table 1. Data Description

The data analysis in this study was performed using repeated measure MIX MANOVA test, Table 2. It was intended to examine the effectiveness of the psychoeducational group with group exercises technique which was aimed at improving self-efficacy in pretest, posttest, and follow-up.

\begin{tabular}{lccc}
\hline & Self Efficacy & & \\
\hline Effects & $\mathrm{F}$ & $\mathrm{Df}$ & $\mathrm{P}$ \\
Time & 1.746 & 2 & $<0.05$ \\
Group & 8.442 & 3.984 & $<0.05$ \\
Time* Group & 0.045 & 1.293 & $<0.05$ \\
\hline
\end{tabular}

Table 2. The Results of Repeated Measure MIX MANOVA Analysis

The results of repeated measure MIX MANOVA showed the effect of time on the improvement of self-efficacy gained $(\mathrm{F}(2)=1,746, \mathrm{p}<0.05)$. The group effect also had the same thing, even it has got significant difference, namely $(\mathrm{F}(3,984)=8,442, \mathrm{p}<0.05)$. Another result showed the effect of time interaction and the group on the improvement of self-efficacy was $(F(1,293)=0.045, p<0.05)$. In brief, it could be concluded that the psychoeducational group with group exercises technique was effective to improve self-efficacy.

\begin{tabular}{rlll}
\hline \multicolumn{5}{c}{ Self-efficacy } \\
\hline T1-T2 & 0.143 & 0.373 & $<0.05$ \\
T1-T3 & 0.571 & 0.429 & $<0.05$ \\
T2-T3 & 0.429 & 0.364 & $<0.05$ \\
\hline
\end{tabular}

Table 3. The Results of Pairwise Comparison

Table 3 shows the improvement based on the comparison of time effects ranging from (T1T2), (T1-T3) and (T2-T3). This could be interpreted that there was self-efficacy improvement in every measurement phase.

The experimental group contributed the self-efficacy improvement. It was showed by the differences in the scores of pretest, posttest, and follow-up. Oppositely, the control group had no changes. Its scores remained the same in the phases of pretest, posttest, and follow-up. It can be concluded that the psychoeducational group with group exercises technique was effective to improve academic hardiness and self-efficacy. 
The findings indicated that the provision of the psychoeducational group with group exercises technique was effective to improve self-efficacy. These are supported by the study of Arvita \& Yustiana (2015) which discussed the program of group counseling service with group exercises technique. Her study concludes that this treatment can provide real experiences for the junior high school students at Childcare Social Protection Home, Bandung by establishing positive beliefs, improving self-control ability, improving stress management ability, being assertive people, and having problem solving ability. This intervention also made the students motivated to be better. Some of them even said that the counseling made them feel happier and not in a bad mood because they could play and laugh together to release boredom and stressful feelings.

Yusuf (2011) findings also support the result of the current study. The investigation of 300 respondents concludes that there is a direct and indirect impact of study components and academic achievement. His findings conclude that self-efficacy is the strongest factor for academic success. Specifically, Yusuf's data analysis shows that there is a direct impact of self-efficacy, and indirect impact of achievement motivation and learning strategies on the academic achievement.

The self-efficacy is a belief on what can be done by someone, self-assessment, and capability to render the abilities into actions (Schunk \& DiBenedetto, 2020; Schunk et al., 2012). Obviously, students with high self-efficacy tend to do harder effort in facing difficulties, while those with low self-efficacy are easy to give up when facing difficulties in learning, and unsure about their abilities.

Students who have good self-efficacy are more enthusiastic in the learning process, so they gain better comprehension in academic field than those who have low self-efficacy. Selfefficacy is an influential matter for motivation and achievement. However, this state can change because of preparation, physical condition (illness, and tired), and one's social environment (general social class condition). If students perform good preparation in facing a test or activity held by schools, their efficacy will be good, and vice versa.

The above explanation is in accordance with Bandura (1977) that personal efficacy can be gained, improved or reduced, through one or the combination of four sources 1) experience of something (mastery experiences), 2) social modeling, 3) social persuasion, and 4) physical and emotional conditions. Experience will improve students' self-efficacy, while repeated failures will reduce self-efficacy, especially when one's efficacy is not strong enough to face failures. The failures can reduce students' self-efficacy when the students do not realize their efforts or external circumstances. This may also be influence by other students' experiences.

By referring to the findings, guidance and counseling teachers should realize the importance of assisting students in improving self-efficacy by providing psychoeducational group with group exercises technique. It is said so because based on the results of the study, this counseling was effective to improve self-efficacy. Meanwhile, the future researchers are suggested to use this study as an alternative as a basic understanding in advancing the study of the psychoeducational group with group exercises technique to help students solve their problems, especially regarding the improvement of self-efficacy.

\section{CONCLUSIONS}

According to the findings, it can be concluded that the psychoeducational group with group exercises technique is effective to improve students' self-efficacy. This study can be used by related parties, such as guidance and counseling teachers or counselors in overcoming students' problems, particularly the students who have low self-efficacy.

The guidance and counseling teachers are expected to provide the psychoeducational group with group exercises technique to help students solve their problems. Furthermore, the 
future researchers who are interested in conducting studies with the same topic are recommended to control variables which influence both psychoeducational group and group exercises technique to improve the internal validity.

\section{ACKNOWLEDGMENTS}

The authors would like to thank Dr. Anwar Sutoyo., M.Pd. and Dr. Awalya., M.Pd., Kons. as the supervisors and expert validators in this study. The same also goes for Public Vocational High School 7 Bandung which has given permission, opportunities and time to conduct the study.

\section{AUTHOR CONTRIBUTION STATEMENTS}

RWP has conducted preliminary study, prepared research design, collected the data in the field, and provided treatments to the subjects at the research site. MEW and MJ have given guidance, instruction, criticisms, and suggestions in the preparation of research designs and supervision when the research process took place.

\section{REFERENCES}

Ana, A., Wibowo, M. E., \& Wagimin, W. (2017). Bimbingan Kelompok dengan Teknik Role Playing untuk Meningkatkan Self-Efficacy dan Harapan Hasil (Outcome Expectations) Karir Siswa. Jurnal Bimbingan Konseling, 6(1), 49-53. Retrieved from Google Scholar

Arvita, L. D., \& Yustiana, Y. R. (2015). Program Layanan Bimbingan Kelompok Dengan Teknik Group Exercises Untuk Meningkatkan Keterampilan Coping Pada Remaja. Edusentris, 2(3), 227-240. Retrieved from Google Scholar

Bandura, A. (1977). Self-efficacy: Toward a unifying theory of behavioral change. Psychological Review, 84(2), 191-215. https://doi.org/10.1037/0033-295X.84.2.191

Brady, S. T., Hard, B. M., \& Gross, J. J. (2018). Reappraising test anxiety increases academic performance of first-year college students. Journal of Educational Psychology, 110(3), 395-406. https://doi.org/10.1037/edu0000219

Cassidy, S. (2015). Resilience Building in Students: The Role of Academic Self-Efficacy. Frontiers in Psychology, 6. https://doi.org/10.3389/fpsyg.2015.01781

Chiaburu, D. S., \& Lindsay, D. R. (2008). Can do or will do? The importance of self-efficacy and instrumentality for training transfer. Human Resource Development International, 11(2), 199-206. https://doi.org/10.1080/13678860801933004

Costa, R., Serrano, M. A., \& Salvador, A. (2016). Importance of self-efficacy in psychoendocrine responses to competition and performance in women. Psicothema, 28.1, 66-70. https://doi.org/10.7334/psicothema2015.166

Frazier, P., Gabriel, A., Merians, A., \& Lust, K. (2019). Understanding stress as an impediment to academic performance. Journal of American College Health, 67(6), 562570. https://doi.org/10.1080/07448481.2018.1499649

Gündüz, B. (2012). Self-Efficacy and Burnout in Professional School Counselors. Educational Sciences: Theory \& Practice, 12(3), 1761-1767. Retrieved from Google Scholar

Harter, S. (2015). The Construction of the Self, Second Edition: Developmental and Sociocultural Foundations. Guilford Publications. Retrieved from Google Scholar

Hyun, M.-S., Chung, H.-I. C., \& Lee, Y.-J. (2005). The effect of cognitive-behavioral group therapy on the self-esteem, depression, and self-efficacy of runaway adolescents in a shelter in South Korea. Applied Nursing Research, 18(3), 160-166. https://doi.org/10.1016/j.apnr.2004.07.006

Jacobs, E. E., Masson, R. L. L., Harvill, R. L., \& Schimmel, C. J. (2011). Group Counseling: Strategies and Skills. Cengage Learning. Retrieved from Google Scholar 
Novita, L., \& Hidayah, N. (2016). Pengembangan Panduan Pelatihan Efikasi Diri Dalam Hubungan Pertemanan Melalui Strategi Experiential Learning Bagi Siswa SMP. Jurnal Kajian Bimbingan Dan Konseling, 1(2), 79-89. Retrieved from Google Scholar

Nurihsan, J. (2007). Buku Materi Pokok Perkembangan Peserta Didik. PPS Universitas Pendidikan Indonesia. Retrieved from Google Scholar

Purwanto, E. (2013). Metode Penelitian Kuantitatif. Fakultas Ilmu Pendidikan Universitas Negeri Semarang. Retrieved from Google Scholar

Riduwan. (2012). Dasar-dasar Statistika. Bandung: Alfabeta. Retrieved from Google Scholar

Rotter, J. B. (1954). Social learning and clinical psychology. Prentice-Hall, Inc. https://doi.org/10.1037/10788-000

Schaffhuser, K., Allemand, M., \& Schwarz, B. (2017). The Development of SelfRepresentations During the Transition to Early Adolescence: The Role of Gender, Puberty, and School Transition. The Journal of Early Adolescence, 37(6), 774-804. https://doi.org/10.1177/0272431615624841

Schunk, D. H., \& DiBenedetto, M. K. (2020). Motivation and social cognitive theory. $\begin{array}{llll}\text { Contemporary Educational } & \text { Psychology, } & 60, & \end{array}$ https://doi.org/10.1016/j.cedpsych.2019.101832

Schunk, D. H., Meece, J. R., \& Pintrich, P. R. (2012). Motivation in education: Theory, research, and applications. Pearson Higher Ed. Retrieved from Google Scholar

Septiningtyas, Q. I. (2020). Hubungan efikasi diri dan motivasi berprestasi siswa kelas XI SMA Negeri 9 Malang. Undergraduate Thesis of UM. Retrieved from Google Scholar

Setiawan, M. A. (2015). Model Konseling Kelompok Dengan Teknik Problem Solving Untuk Meningkatkan Self-Efficacy Akademik Siswa. Jurnal Bimbingan Konseling, 4(1). Retrieved from Google Scholar

Shechtman, Z., Levy, M., \& Leichtentritt, J. (2005). Impact of Life Skills Training on Teachers' Perceived Environment and Self-Efficacy. The Journal of Educational Research, 98(3), 144-155. https://doi.org/10.3200/JOER.98.3.144-155

Shimazu, A., Kawakami, N., Irimajiri, H., Sakamoto, M., \& Amano, S. (2005). Effects of Web-Based Psychoeducation on Self-Efficacy, Problem Solving Behavior, Stress Responses and Job Satisfaction among Workers: A Controlled Clinical Trial. Journal of Occupational Health, 47(5), 405-413. https://doi.org/10.1539/joh.47.405

Sohrabi, R., Mohammadi, A., \& Aghdam, G. A. (2013). Effectiveness of Group Counseling with Problem Solving Approach on Educational Self-efficacy Improving. Procedia Social and Behavioral Sciences, 84, 1782-1784. https://doi.org/10.1016/j.sbspro.2013.07.033

Stajkovic, A. D., Bandura, A., Locke, E. A., Lee, D., \& Sergent, K. (2018). Test of three conceptual models of influence of the big five personality traits and self-efficacy on academic performance: A meta-analytic path-analysis. Personality and Individual Differences, 120, 238-245. https://doi.org/10.1016/j.paid.2017.08.014

Sunawan, S., Yani, S. Y. A., Anna, C. T., Kencana, T. I., Mulawarman, -, \& Sofyan, A. (2017). Dampak Efikasi Diri terhadap Beban Kognitif dalam Pembelajaran Matematika dengan Emosi Akademik sebagai Mediator. Jurnal Psikologi, 44(1), 28-38-38. https://doi.org/10.22146/jpsi.22742

Tompson, G. H., \& Dass, P. (2000). Improving Students' Self-Efficacy in Strategic Management: The Relative Impact of Cases and Simulations. Simulation \& Gaming, 31(1), 22-41. https://doi.org/10.1177/104687810003100102

Walpole, B., Dettmer, E., Morrongiello, B. A., McCrindle, B. W., \& Hamilton, J. (2013). Motivational Interviewing to Enhance Self-Efficacy and Promote Weight Loss in Overweight and Obese Adolescents: A Randomized Controlled Trial. Journal of Pediatric Psychology, 38(9), 944-953. https://doi.org/10.1093/jpepsy/jst023 
Wang, L., Tao, H., Bowers, B. J., Brown, R., \& Zhang, Y. (2018). Influence of Social Support and Self-Efficacy on Resilience of Early Career Registered Nurses. Western Journal of Nursing Research, 40(5), 648-664. https://doi.org/10.1177/0193945916685712

Yusuf, M. (2011). The impact of self-efficacy, achievement motivation, and self-regulated learning strategies on students' academic achievement. Procedia - Social and Behavioral Sciences, 15, 2623-2626. https://doi.org/10.1016/j.sbspro.2011.04.158

Zaroh, S. (2018). The Impact of Experimental Learning Techniques in Improving the Capability of Career Planning for Students. Islamic Guidance and Counseling Journal, 1(2), 45-52. https://doi.org/10.25217/igcj.v1i2.233

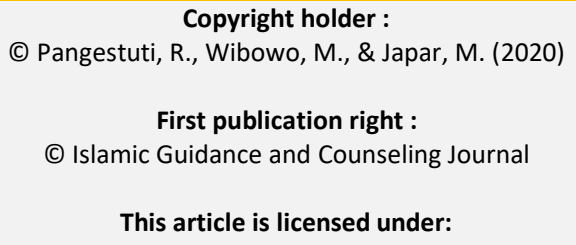

